Article

\title{
Extended Urbanization through Capital Centralization: Contract Farming in Palm Oil-Based Agroindustrialization
}

\author{
Isnu Putra Pratama* $*$, Haryo Winarso, Delik Hudalah and Ibnu Syabri \\ School of Architecture, Planning and Policy Development, Bandung Institute of Technology, Ganeca Street No. 10, \\ Bandung 40132, Indonesia; hwinarso@pl.itb.ac.id (H.W.); d.hudalah@sappk.itb.ac.id (D.H.); \\ syabri@pl.itb.ac.id (I.S.) \\ * Correspondence: Putraisnu@gmail.com
}

Citation: Pratama, I.P.; Winarso, H.; Hudalah, D.; Syabri, I. Extended Urbanization through Capital Centralization: Contract Farming in Palm Oil-Based Agroindustrialization. Sustainability 2021, 13, 10044

https://doi.org/10.3390/su131810044

Academic Editor: Juan Miguel Kanai

Received: 8 July 2021

Accepted: 4 September 2021

Published: 8 September 2021

Publisher's Note: MDPI stays neutral with regard to jurisdictional claims in published maps and institutional affiliations.

Copyright: (c) 2021 by the authors. Licensee MDPI, Basel, Switzerland. This article is an open access article distributed under the terms and conditions of the Creative Commons Attribution (CC BY) license (https:// creativecommons.org/licenses/by/ $4.0 /)$.

\begin{abstract}
The discussion on extended urbanization considers accumulation by dispossession as a key apparatus for instilling urban logic into predominantly rural areas. This paper contends that extended urbanization can also be produced without physical dispossession of community land. This is illustrated by the case study of Sei Mangkei, an emerging palm oil agroindustrial district in North Sumatra, Indonesia. Capitalist industries prefer monetization through contract farming rather than privatization as an instrument to capture the productivity of palm oil smallholder land. The people who serve as smallholders in the palm oil industry are not victims of land appropriation. Moreover, this situation was also triggered by an opportunity for maximizing the socio-economic welfare of smallholders. However, the limited options to access other economic activities when the commodity crisis occurred was a consequence that smallholders were not aware of in the past. Thus, we assert that extended urbanization was (re)produced through the articulation of socio-economic and cultural practices of smallholders on a local-scale with regard to the dynamics of the broader process of global industrialization.
\end{abstract}

Keywords: planetary urbanization; extended urbanization; multiscalar urbanization; resource extraction; palm oil industrialization; Indonesia

\section{Introduction}

There are two sides to the coin of the wave of globalization, not only in terms of the acceleration of the flow of goods and capital on a global scale but also the production of a new socio-spatial configuration of space enabling this accelerated movement [1]. Consequently, new spaces such as export-oriented industries in rural landscapes have emerged and intensified amid capital seeping into various geographical spaces. As the world's largest palm oil exporter, Indonesia has experienced this kind of space transformation on an expansive scale. The amount of land used for large-scale palm oil plantations almost tripled between 2000 and 2017, from 4,158,077 ha to 12,307,677 ha (mostly in rural areas), and it is expected to grow further due to the increasing global demand for vegetable oil and biofuel [2]. Hence, the palm oil industry represents how industrialization operationalizes and reconfigures rural areas for pursuing surplus value in the geohistory of global capitalism.

In academic publications, this contemporary global industrial hegemony dominating rural space has prevalently been examined through the framework of extended urbanization. The notion of extended urbanization was introduced by Lefebvre [3] as a particular feature of capitalist urbanization, which 'exploded' from conventional zones of urban agglomeration and extended its operational landscape to large-scale spatial formation beyond these zones. Monte-Mór [4] used the phenomenon of extended urbanization to illustrate the total integration of all social spaces (city and countryside) in Brazil under the auspices of the extension of the urban-industrial fabric. The incorporation of resource extraction areas into global processes of urban development blurs the distinction between the urban 
and the rural [5]. In the sense of urbanization as a capital accumulation process, as stated by Harvey [6], the notion that industry is based on accumulation (profit) and production (market) pertains to both urban and rural areas [7]. Since the characteristics of both areas are increasingly blurred, extended urbanization provides a useful framework for probing permeating capitalist industrialization networks and the socio-spatial transformation of rural space.

The notion of extended urbanization perceives urbanization as synonymous with the logical process of how capitalism transforms rural society into urban society. Brenner and Schmid [8] (p. 167) emphasize that this site/process is operationalized through the enclosure of land from established social and subsistence uses (use value) in favor of privatized, exclusionary, and profit-oriented modes of appropriation (exchange value). By using extra-economic coercion, capitalists take over subsistence, production, or shared social wealth [9]. Rural space that has experienced dispossession and expropriation of communal or community land is converted from subsistence farming to an instrument for revenue extraction through the commodification of urban-industrial praxis (see [10-13]). This process is frequently facilitated and enforced by state capitalist regimes under neoliberal economic policies [8]. In summary, dispossession is a prerequisite and key apparatus of extended urbanization for producing new urban territories of capitalism [14,15]. Contrary to this assumption, this paper challenges the notion that extended urbanization processes only hinge upon land dispossession. We argue that extended urbanization as capital accumulation can also occur through capital centralization.

This article aims to show how the processes of extended urbanization without land dispossession occur in Sei Mangkei as an agroindustrial site in the rural region of North Sumatra, Indonesia. By using the notion of centralization to explain the practice of contract farming, we illuminate the social relations of capitalism that form the basis for extended urbanization without dispossession in the landscape of agroindustrial capitalism. Marx [16] referred to centralization as the accumulation process built upon the mechanism of social capitalist integration between independent capital (smallholders) and larger capitalist enterprises. Furthermore, we explore the transformations and struggles of daily life of palm oil smallholder communities under the connectedness and tension of global industrial activity. We believe this theorization usefully complements the emerging scholarly ideas of extended urbanization and planetary urbanization [17-19] and enriches the plurality of possible outcomes of global capitalist urbanization under today's particular, differentiated, and unique urban space $[17,18]$.

We argue that instead of removing the local community through physical dispossession of land and property assets, urbanization extends through the establishment and commodification of palm oil plantations by the community in their land setting. Based on this condition, the community becomes a collection of smallholders (farmers) that sell and supply the raw material of this commodity (extracted from their land) to large enterprises. Moreover, our results show that although dispossession and social resistance are absent in the case studies, global market integration and dependence into palm oil smallholder's life causes uncertainty regarding their future. This situation was realized when global palm oil prices became unfavorable to palm oil smallholders. Finally, it can be said that emerging new forms of extended urban society struggling against accumulation without dispossession and negotiating with the broader process of capitalist industrialization are worth exploring.

The remainder of this article is organized into several sections. In the next section, we outline an explanation of the Sei Mangkei palm oil-based agroindustrial estate as a case study and the methods that were used in carrying out this research. The third section develops the main theoretical arguments and framework about extended urbanization under capital centralization. Then, the fourth part explores the longue durée expansion of palm oil-based industrial extraction in Indonesia to understand the wider context of socio-spatial capitalist restructuring in extended urbanization space. The fifth section applies the theory of extended urbanization and centralization of capital to the case study. 
The sixth section explains the everyday life and struggle of palm oil smallholders as the outcome of the extended urbanization process through capital centralization. In conclusion, we briefly return to the possibility of an emancipatory process towards equal urbanization as an alternative to the domination of exchange value in extended urbanization space.

\section{Research Case and Methods}

We empirically examined the transformation of socio-spatial urban conditions in the Sei Mangkei Industrial District and its related palm oil production chain, such as smallholder villages. This space has experienced the history of accumulation strategies of the agricultural industry in Indonesia, from the Dutch colonial period to the contemporary neoliberal state strategy of Special Economic Zones (SEZ). At the moment, this space is promoted by the government as a strategic global industrial zone and a new center of economic growth. The Sei Mangkei Industrial District is located in Sei Mangkei village, where 1975 hectares $(90 \%)$ of the land are taken up by palm oil plantations and production facilities, while the rest is a residential zone for the village community (see Figure 1). The site is part of Simalungun Regency, one of the regions with a productive palm oil industry in North Sumatra Province [19]. Sei Mangkei is an illustration of the operational landscape produced by capitalist industrial expansion in the countryside; it has a peripheral space of $132 \mathrm{~km}$ and is a $3 \mathrm{~h}$ drive away from the Medan Metropolitan Area.

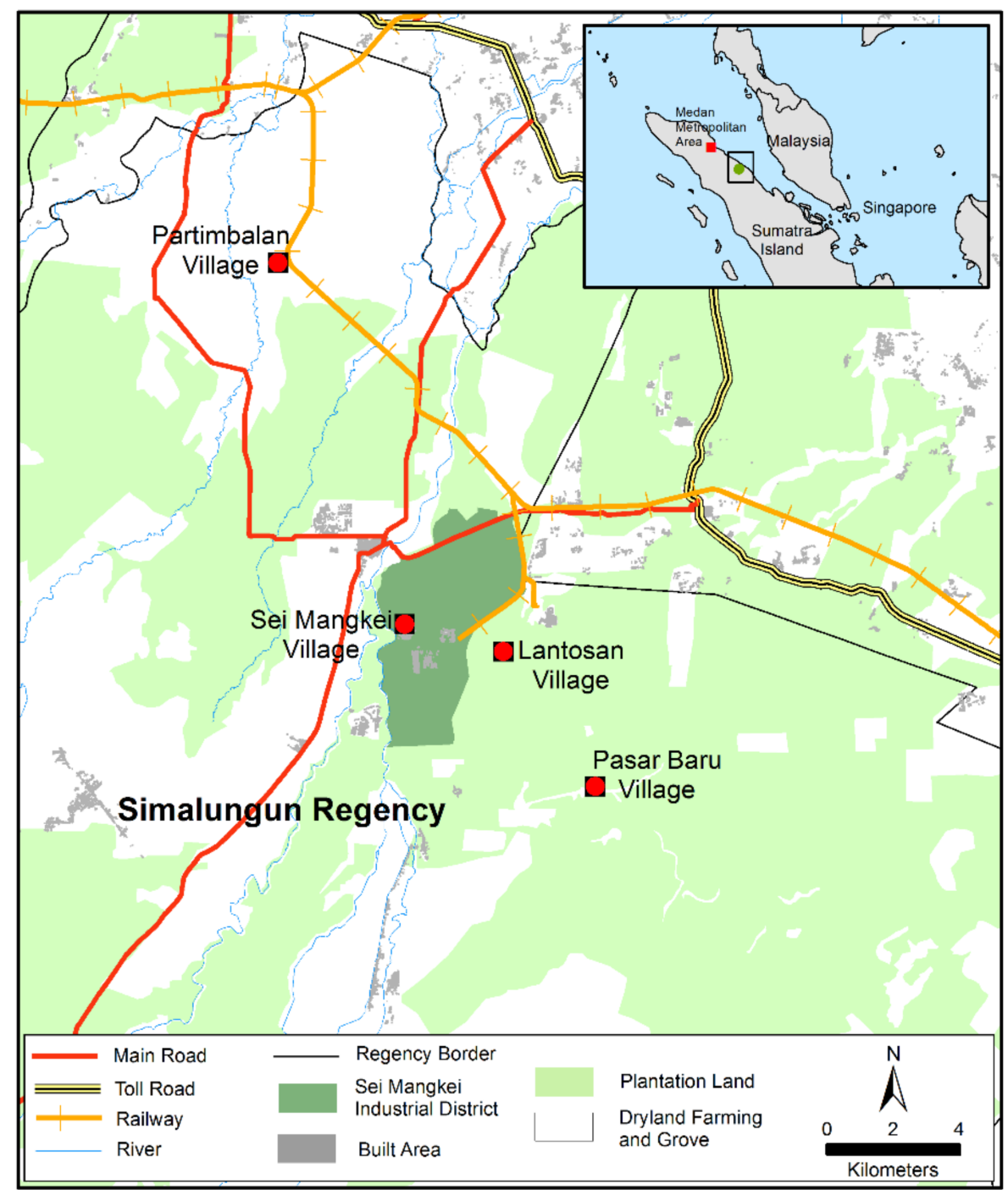

Figure 1. Sei Mangkei industrial district, North Sumatra (source: adapted from The Ministry of Environment and Forestry [20]). 
Several multinational enterprises joined Sei Mangkei SEZ, and the area successfully gained around USD 70 million of foreign investment, which could be worth double if we consider the supporting infrastructure [21]. As new enterprises were involved in the palm oil industry downstream, the demand for palm oil fruit increased in the Sei Mangkei factories. Consequently, the enterprise management of Sei Mangkei SEZ used a contractfarming policy to cooperate with several palm oil smallholder farmers around the regency of Simalungun. Smallholder farmers regularly supply their fresh fruit bunches of palm oil to Sei Mangkei industrial district through the local co-operative agencies (see Figure 2). After being processed in the factory and refinery, the fruit is used to produce export-ready intermediate products such as Crude Palm Oil, Palm Kernel Oil, and Basic Oleochemicals.
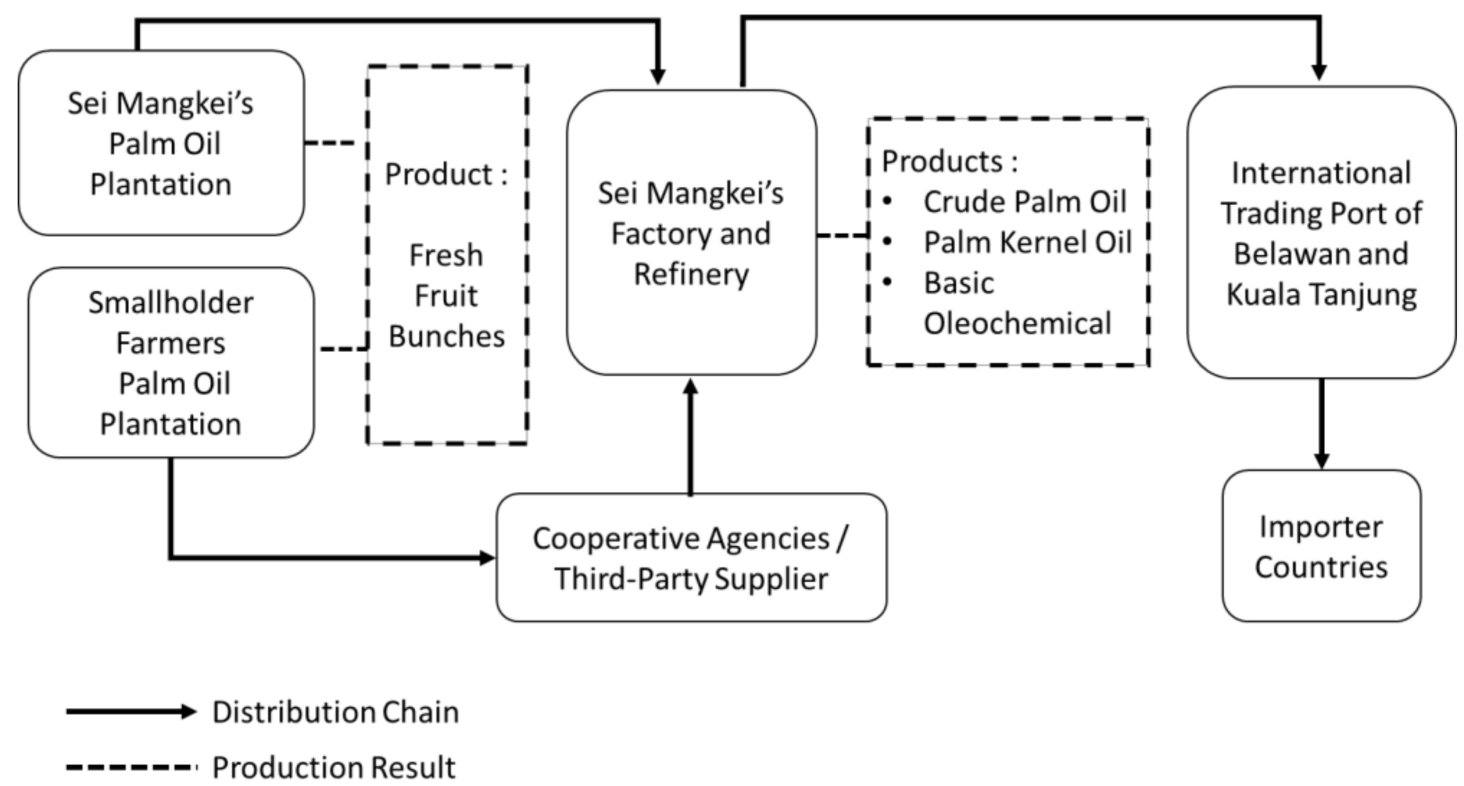

Figure 2. Distribution chain of palm oil industry in Sei Mangkei industrial district (Source: Author (2020)).

We collected data during fieldwork from August to December 2019. Interviews were conducted in Jakarta and North Sumatra with four main groups of informants. The first group comprised representatives from the state government (National Council of SEZ), the local government of North Sumatra province, and the Simalungun Regional House of Representatives. These interviews provided the governmental perspective in terms of planning and development of Sei Mangkei SEZ. The second group of interviewees comprised representatives from enterprises doing business in SEZ. They represent the capitalist actor that runs industrial activities. The last two groups comprised representatives from local communities of Lantosan village, which is located around Sei Mangkei Industrial District, and palm oil smallholder farmers who affiliated their production activities with Sei Mangkei Industrial District. The smallholder farmer villages are Partimbalan and Pasar Baru, which are still located in the Simalungun Regency (see Figure 1). In total, there were 30 people whom we interviewed during the fieldwork. This qualitative data interview was triangulated by multiple key informants, secondary materials (i.e., enterprise reports and policy documents), and other literature.

\section{Capital Accumulation under Extended Urbanization}

A representation of extended urbanization in the present stage of industrial capitalism can be found in the urban fabric. The urban fabric manifests itself across a region in the built environment (infrastructure, housing, supermarkets, etc.) and social praxis as the forces and relations of accumulation $[3,4,6]$. Based on this, we can say that capitalist industrial rural space has undergone urbanization. Thus, rural space has lost autonomy and subsistence since it has become an integral part of industrial production and consumption. The 
subsumption of an industrial capitalistic logic in rural realms involves pivotal alterations to urban society. Sevilla-Buitrago [15] defines the initial phase of extended urbanization as 'original extended urbanization', a dismantling process from "self-contained rural lifeworlds and divisions of labor through an intensified connection and subsumption of the countryside by which it increasingly becomes a mere functional appendix of the broader urban networks that command socio-spatial organization under capitalism" (p. 241).

In short, the industrialization of society always implies urbanization, and the urban refers to "the society that results from industrialization" [3] (p. 2). In the current neoliberal regime, rural areas are transformed into strategic spaces in the form of operational landscapes of various urban spaces on a planetary scale to grow and develop through the supply of commodities [8]. Hence, we suggest that extended urbanization is as a prominent analytical lens through which the limitations of a city-centric approach for understanding the broader capitalist urbanization processes beyond the city become visible [22].

We understand global industrial capitalism as the main driving force of extended urbanization [23]. The process of accumulation thus becomes a central point in the analysis of extended urbanization. Empirical studies have shown that accumulation by dispossession is the nature of this accumulation [10,13,24]. Marx [16] pointed out that the early stage of this accumulation occurs through 'primitive accumulation'. Following Marx's concept, Harvey [24] argued that the process of primitive accumulation, popularly known as accumulation by dispossession, is a continuous element of contemporary accumulation rather than a historical stage of capitalist development. For Harvey, accumulation by dispossession means "the commodification and privatization of land and the forceful expulsion of peasant populations; the conversion of various forms of property rights (common or collective) into exclusive private property rights", thereby increasing accumulation [24] (p. 145). Within the extended urbanization landscape, accumulation by dispossession is enforced by various strategies against communities or indigenous people, such as displacement, violence, marginalization, exclusion, and ecological degradation $[4,10,12,25]$.

Capitalist industrialization deploys accumulation by dispossession to create and perpetuate the process of accumulation. However, it has a tendency to disrupt and replace the previous socio-spatial configuration [25,26], also known as 'creative destruction' [8]. In this sense, extended urbanization can be understood as a double movement. On the one hand it functions as a productive force, which helps to trigger waves of industrialization; on the other hand it represents a social relationship in which human everyday life is organized and reproduced [27]. Hence, extended urbanization must be understood in terms of contradictory socio-spatial relations, which are constructed by the assembly of capital accumulation and social practice within the dynamics of capital accumulation. Thus, extended urbanization implies a multiscalar process of production and reproduction of the built environment in which global structures of capital and local everyday practices become interlinked [3]. Both the global scale of structural forces and the local scale of everyday life experience urbanization process so that they can, and do, spiral up to affect the 'urban' as a mediating scale (Angelo and Goh, 2020) and materialize the process into a specific socio-spatial configuration of urban space. As a result, urban everyday life becomes a seedbed of struggle for acquiring any 'right to the city' as a consequence of extended urbanization by dispossession $[10,28]$.

In contrast with the main assumptions and evidence of extended urbanization by dispossession, another form of capital accumulation in rural areas can occur without dispossession. Some scholars emphasize that accumulation is not only realized under the capitalist regime of violent and physical appropriation but also in the tendency to integrate through centralization of capital [29,30]. Centralization occurs when "capitalists borrow and merge, gathering the existing resources of capitalist production" [31] (p. 75). In the landscape of agroindustrial capitalism, this kind of accumulation is realized under the contract-farming scheme. According to Little and Watts [32], we can understand contract farming as: 
"Forms of vertical coordination between growers and buyers-processors that directly shape production decisions through contractually specifying market obligations (by volume, value, quantity, and, at times, advanced price determination), provide specific inputs, and exercise some control at the point of production".

(p. 9)

Marx emphasized that centralization of capital causes "many people [ ... ] to lose their access to capital in order for a few others to gain and grow", [30] (p. 83), or in the worst condition, individual capitals are absorbed and destroyed by big capitals [33] (p. 27). However, centralization through contract farming allows corporate capital to accumulate profit without owning the land (privatization); in other words, land acquisition by dispossession does not happen [30]. The existence of the contract-farming scheme encourages communities to commodify their land, taking it from subsistence production to industrial resource extraction based on exchange value. Under the legal 'partnership' of contract farming, community farmers experience a shift in the labor process through a new landscape of commodity and become dependent on industry (a wage-labor relationship). Hence, contract farming is a vehicle of agroindustrial capitalism for instilling capital logic into the subsistence social formation of rural farmers [29]. However, since extended urbanization holds a multiscalar perspective, we also have to understand the dynamics and socio-spatial context on a local scale where rural farmers practice everyday life. This means that dialectical methods and thinking (global-local) must be paid more attention in analyzing capital centralization and contract farming itself.

\section{Capitalist Expansion of Palm Oil-Based Industry in Indonesia}

The longue durée expansion of palm oil-based extraction in Indonesia characterizes the pattern of socio-spatial capitalist restructuring in extended urbanization space. However, capitalist urbanization is always a historically and geographically multilayered process since it is mediated by the dynamic transformation of institutions, political and accumulation strategies, environment landscapes, and struggles [8]. Therefore we intended to track and unpack the expansion of palm oil industries in Indonesia. This also strengthens the context of further analysis in the case study.

The palm oil tree was brought to Indonesia by the Dutch colonial state and was first planted in the east coast of Sumatra as an ornamental plant on tobacco estates in 1848 [34]. In the early 20th century, the Dutch initiated their strategy of palm oil commodity accumulation because rubber, tobacco, and sugar were no longer able to compete in the global market. In 1919, the first milestone in the export of the Dutch colonial state palm oil to the world market occurred [35]. The industrial revolution promoted the increasing demand for palm oil products across the world, both for household needs such as soap, candles, and medicinal ointments, and for machine lubrication in the manufacture industry [36]. On the east coast of Sumatra, intensification of the palm oil industry was mostly carried out by multinational enterprises. Under the mercantilism of the Dutch colonial state, the palm oil production on the east coast of Sumatra grew significantly, from 181 tons of palm oil in 1919 to almost 191,000 tons in 1937 [37].

After independence was declared in 1945, the Indonesian government saw that palm oil commodities had the potential to contribute to economic growth. In the late 1960s, Soeharto's regime reformulated the regulations for financing development by foreign aid. The colonial enterprises were reorganized into state-owned enterprises (SOE), called Perseroan Terbatas Perkebunan (PTP) and later Perseroan Terbatas Perkebunan Negara (PTPN). From the early 1980s, through cooperation with PTPNs and several private palm oil enterprises, the government encouraged the active involvement of smallholder farmers as a new scheme of palm oil expansion [38]. The program was called Perkebunan Inti Rakyat (PIR), or the Nucleus Estate Scheme (NES). The NES program introduced the first contract-farming scheme in Indonesia's palm oil sector. Backed by the World Bank and credit funds from the Asian Development Bank, this program was expected to provide economic benefits and to alleviate the poverty of local communities and smallholders [39]. 
Contract farming through the NES program created two interconnected systems: the core/nucleus and the plasma. The former refers to the core plantation of the enterprise, usually around an industrial mill ( $20 \%$ of total land), while the latter refers to the periphery of the nucleus ( $80 \%$ of total land), which is under the enterprise's supervision but is allocated to smallholders under partnership contracts [40]. Smallholders could be local people or transmigrant people (usually from Java and Bali). The enterprises had free access to land to exploit palm oil resources. The land could be hailed from state land or local landowners that donated their land to the state through the contract-farming scheme of NES. Then, the smallholders can obtain their land with palm oil crops after the contract was over [38]. Later, the government upgraded the contract-farming scheme of NES through the KKPA (Primary Credit Cooperative for Members) program. This involved a more direct private-community 'partnership' model, with the plantation firm being responsible for nearly all the projects, working directly with the participating farmers to resolve land problems and providing training and extension. Under this scheme, smallholders organized in local cooperative units (koperasi) were able to access subsidized loans from banks. It advised the government to officially abandon its direct subsidizing role and leave oil palm development to the market [38].

Following the economic crisis in 1997, the state suffered from political and social crises, which ended three decades of high economic growth under the New Order government. In 1998 Indonesia turned to the IMF, which arranged a 'stabilization package', requiring a fundamental restructuring of the banking sector, such as withdrawing Bank Indonesia from direct development financing [41]. The dismantling of Bank Indonesia's role in distributing liquidity credit ended the flow of state funds to palm oil smallholders. Pertinent to palm oil expansion, intensification of deregulation in the industrial sector aimed to promote economic growth. In 2014, the Indonesian government attempted to designate Special Economic Zones (SEZ) as strategic industrial spaces to increase economic growth as well as export competitiveness through domestic and foreign investment, including in the palm oil sector. It is a representation of the neoliberal strategy for liberating industrial development and modernizing rural space under the direct control of the state. Sei Mangkei is the most progressive example of Special Economic Zone development compared to the other 14 Special Economic Zones in Indonesia.

\section{Extended Urbanization Processes}

This section analyzes the emergence of extended urbanization through a case study of the industrialization process of Sei Mangkei. The initial phase of extended urbanization can be seen in the moment of original accumulation. In the context of the case study, the moment of initial extended urbanization is reflected in two processes related to different moments in space and time. The first was the original accumulation at the main site of palm oil industrial production. The second was the process of expansion of the original extended urbanization on small-scale community palm oil lands that supplied raw materials to the main site. If the former tells us how the extended urbanization space was first formed through the homogenization of space by the state, the latter was a form of expansion capital in search for new space to accumulate. The second stage was a crucial moment in terms of extended urbanization without land dispossession and people displacement.

\subsection{Initial Extended Urbanization}

Sei Mangkei Industrial District is an urban-industrial extension into the countryside. Industrial logic formed by agroindustrial intensification has occurred since the era of colonial mercantilism. Global demand for rubber and palm oil was captured by the Dutch colonial state to initiate and rescale the operational landscape of accumulation. Sei Mangkei is proof of the colonial state's ambitions to be involved in the early 20th century's developing capitalist world system. Sei Mangkei first was a plantation for rubber, which was a commodity until the 1970s. The site was only a resource extraction space that 
supplied its crops to industrial hubs in other districts, which would then proceed to export their products to foreign countries.

The Dutch colonial state issued the Agrarian Law in 1870 as an instrument for private enterprises to be able to exploit productive land. Sei Mangkei was part of the wider east coast of Sumatra (Deli) plantations, owned by a local Sultanate (called Kerajaan Tanah Jawa). The plantation concession was a civil agreement between the Sultan, representing indigenous customary communities, with Dutch plantation enterprises [42]. Waal [43] states that a plantation concession is an individual right, in this case based on an agreement between the Sultan and the concessionaire. The colonial leasing agreement rented the land for between 75 and 99 years. However, this agreement included several clauses that involved customary land and its inhabitants. While the empty customary land was transformed into rubber plantations by a Dutch plantation enterprise (Rubber Cultuur Maatschapij Amsterdam, RCMA), they allowed rural inhabitants to live in a village alongside with the plantation (Lantosan village). Rather than seizing the land of the local people, an agreement was made with local leaders, trying to respect the local people. Stoller [37] noted this as a social stability strategy of the colonial government. However, the Agrarian Law was a key apparatus to transform customary land into industrial commodities based land.

The Dutch colonial state issued a policy to allow the creation of a labor pool from other regions. In Sei Mangkei, laborers were brought in by RCMA from Java Island, called coolies. Thus, a new plantation landscape was formed, but the majority of the local people in the areas surrounding Sei Mangkei industrial district still choose to work as subsistence farmers. Local actor of Lantosan village explained:

"The Dutch enterprise opened the area [initiate the industrial activity], and at the same time, they brought labor force, which was dominantly from the island of Java. There were local recruits, but because the [majority of] community here did not need jobs [agricultural area was still quite large], they did not want to go to plantations [work as a labor]". (Interview, 14 December 2019)

Various new settlement spaces were created to accommodate the new laborers. However, the logic of industrial space under the process of extended urbanization through the commodification of land and proletarianization through labor wage relations also emerged at the same time. The initial accumulation of extended urbanization was increasingly dictated by the conditions of international exchange rationales rather than direct control of the Dutch colonial state. In that era, new industrial clusters were emerging across the country, especially around global resource extraction commodities, most of which were located in remote areas.

After Indonesian independence, Indonesia's government enacted the law of nationalization to transform Dutch colonial enterprises into state owned enterprises. Nationalization took place through political, legal, and economic processes. The legal process was aimed at the transfer of industrial ownership from the colonial state to the Indonesian government. In the economic process, nationalization was interpreted as a transition from a colonial economy to a national economy [44]. In Sei Mangkei, the institutional change of the colonial rubber enterprises was handled by SOEs. The government claimed that nationalization was an agrarian reform agenda.

However, whether or not nationalization was carried out by dispossession of rural land is not an easy question to answer. On the one hand, we can say nationalization is a part of legal dispossession by the state as a strategy to promote the logic of industrial space. On the other hand, from a labor and community perspective, nationalization is a symbol of victory against global imperialism (Dutch enterprises) [37] and feudalism (local kingdom power) (interview with a local actor of Lantosan village, 14 December 2019). The land in Sei Mangkei is not communal or customary land. Hence, the rent agreement was based on the individual rights of the local leader. After independence, the business relationship of land rent between the local leader (the Sultanate) and the Dutch enterprises was disturbed. The local community used this event to mobilize against the Sultanate, which mainly pursued its own interests. Hence, nationalization received 
support from the community in cancelling that private relationship. From the perspective of labor groups, nationalization was a sovereignty symbol of public enterprise and led to the structural management reformation of Indonesian citizens. Nonetheless, Stoler [37] noted that nationalization did not change the labor system and structure of class relations in the North Sumatra plantations.

In this context, we view that the emergence of extended urbanization space was not only produced by the global forces of capital through the Dutch enterprise and state but also cannot be separated from various socio-cultural conditions and practices of local actors that allow the opening of space for industrial extraction. First, there is a conformity of the norms of the Lantosan village community and the natives of the Sei Mangkei area to the use of shared space by other social groups (Dutch plantation enterprise). Second, the state strategy to maintain industrial logic through the nationalization program could be realized because there is harmony and common ground between the grassroots movement against Dutch colonialism and local leader feudalism. These situations then brought Sei Mangkei into the initial process of extended urbanization. Thus, both global and local forces influence socio-spatial reconfiguration of extended urbanization.

\subsection{Palm Oil as an Expansion of Extended Urbanization}

Starting in the 1980s, a significant increase in the price of palm oil on the world market encouraged several big enterprises in North Sumatra province to convert its rubber plantations into palm oil plantations. This situation also affected the emergence of palm oil smallholders who previously worked as subsistence farmers. There are two mechanisms to convert farmer-owned land to palm oil plantations: firstly, communities are involved in the state program of NES (nucleus-plasma), and secondly, communities choose to replace their subsistence lands by their own volition. The NES program is a first implemented contract farming scheme that enables farmers to plant palm oil through cooperation between state, the transmigration department, World Bank, and enterprise plantations in the early 1980s [45]. According to the agreement, the farmers allow the enterprise to plant and manage palm oil crops on their (modified) land for a certain period. Moreover, the enterprise also ensured management funds and trained the smallholders to manage the palm oil plantations. One of the palm oil smallholders in Partimbalan village who supplied to Sei Mangkei factory discussed the motivation of his parents engaged with the NES pilot program from the government:

"The transformation of our land [from subsistence crops] into palm oil are motivated by the promise of higher profits and by the ease of land management".

(Interview, 25 October 2019)

However, after the contract expired, his family obtained full private ownership of their land, including planted land with palm oil crops. The other smallholder in Partimbalan also asserted that her family gained knowledge of the management of palm oil plantations, which is very different from that of subsistence crops, through the NES program (Interview, 25 October 2019). During this period, transition from subsistence to palm oil plantation was not an easy process; it required a transfer of knowledge (land management) and access to credit related to high-quality materials (modern tool, seed, fertilizer, etc.) [46].

The NES program influenced the massive transformation of palm oil smallholders area in North Sumatra during a decade, from $6150 \mathrm{Ha}$ in 1980 to 72,228 Ha in 1990 [47]. The success of the first generation of NES smallholders and palm oil's high returns in relation to both market price and labor have encouraged the second wave of smallholder boom. Thus, from the late 1990s, becoming palm oil smallholders became a massive social movement (interview with palm oil smallholders in Pasar Baru village, 15 December 2019). In Simalungun Regency, there was a threefold increase in the area of smallholder palm oil plantations, from $9963 \mathrm{Ha}$ in 1996 to 27,309 Ha in 2010 [48]. In this second wave of smallholder boom, engaging with contract farming was an optional practice for the people who joined this business for the first time. One reason is that the community could gain basic knowledge of palm oil land management from various sources, such as family, friends, 
or neighbors who are experienced in palm oil production. Yet, both palm oil smallholders in Partimbalan and Pasar Baru village said that contract farming facilitated by koperasi provided several advantages beyond knowledge transfer.

First, smallholders obtain a competitive selling price and certainty of trade for the enterprise by cooperating with palm oil enterprises. Second, contract farming was also opened to the opportunity of accessing loans or capitals from the koperasi or banks (interview with smallholder's koperasi in Partimbalan village 25 October 2019 and palm oil smallholders in Pasar Baru village, 15 December 2019). Thus, it is reasonable to assume that contract farming could be considered a motive of smallholders to engage with palm oil plantations. The reason is that smallholders with access to market certainty, credit, and high-quality planting materials can profit significantly [45].

We believe that the practice of palm oil smallholder land can be understood as an expansion of accumulation during the extended urbanization process. Smallholder land was previously planted by rice, corn, cassava, or other food crops. The farmers harvested the crops, which were prioritized to meet their daily needs. However, if the need was excessive, they could sell it to the local market as an additional income or exchange them for other things. In this context, the farmers prioritize subsistence that utilizes use value, and the market is considered an opportunity. They can still live independently without growing certain high-value crops and exchanging their production in the competitive market.

However, the transformation from subsistence farmers to palm oil plantation smallholders changed their social-economic relations. Firstly, because palm oil is mostly a monoculture, i.e., the land is only planted with one single type of species for the whole season. Secondly, palm oil is not a ready-served food; it must first be processed through a high-tech industrial process before it can deliver the end product. Thirdly, the harvested crop must be processed within a certain time before it decays. Hence, the smallholders have to sell their crops within this time or they lose their money. Fourthly, palm oil is a global commodity, where the demand for this product comes from various countries in the world. Thus, palm oil is a cash commodity crop because it is always connected with the industry and the global market.

The majority of smallholders in our case study are vulnerable to the price crisis of palm oil. The reason is that they have invested most of their capital in their palm oil business and inadequate plots of land to obtain alternative income since all of their lands have been modified into palm oil plantations (Field Notes, 15 December 2019). This smallholder group usually manage less than $5 \mathrm{Ha}$ of palm oil plantation. However, other studies in Indonesia found that it would be insufficient to sustain both farm and family if smallholders manage only $2 \mathrm{Ha}[39,49]$. The option to return to subsistence farming is also not economically viable because it is like starting a new business. These factors are due to the loss of investment for current palm oil land, limited capital, and the palm oil business still being more profitable than subsistence practice.

If smallholders lose the capacity to maintain their business, the last choice is to sell their land as the only production asset they have. For a vulnerable group of smallholders, this situation made the options are limited to realizing the value and profit of their asset except keep selling palm oil fruit to the enterprise. In addition, it is also a reason why contract farming provides a better opportunity for smallholders to obtain market certainty, an additional source of capital, and produce high quality of palm oil fruit. Wood [50] noted this situation as "the market as a compulsion", where smallholders have limited choice to survive except to sell their palm oil production in the market (enterprise). Thus, smallholders' socio-economic relations was shifted from viewing the market as an opportunity to being a market as a compulsion [50]. Under palm oil expansion, lands with food crops that were originally prioritized for use value are now forced to be utilized for exchange value. Extended urbanization understands this process by transforming land in rural areas from prioritized social uses of use value to profit-oriented modes of production based on exchange value rationale space $[4,8]$. 


\subsection{Extended Urbanization through Contract Farming}

The self-transformation of smallholder's palm oil plantations was not a self-evident phenomenon. While the state and enterprises played a crucial role in providing the instruments for palm oil expansion, the smallholders saw this commodity as an opportunity for maximizing their socio-economic well-being through higher profit production. The mechanism for accumulation was contract farming. Contract farming by the palm oil industry works according to the logic of capital centralization. As Shrimali [30] noted, under the centralization of capital through contract farming, smallholders' land has to be consolidated in a 'social' manner rather than by physical encroachment. This allows big enterprises to create a pool of labor (smallholders) and resources to support their industrial operations without owning the land (privatization). A group of palm oil enterprises has claimed that production expansion by investing in the new land is too costly. Accordingly, they prefer to implement intensification strategies through building partnerships (contract farming) with smallholders to make business more efficient (Statement from a member of GAPKI (Indonesian Palm Oil Bussinessman Association) in the public web-seminar 'Mengurai Peta Pemain Industri Sawit Nasional' by the Auriga Institute, 4 May 2020). This practice proves that contract farming facilitates the accumulation process without requiring investment in the new land. However, contract farming is a legal instrument that should work under legal agreements between enterprises and smallholders. In the current policy, the government promotes cooperative agencies (koperasi) to mediate between both actors.

Palm oil smallholders claim they have not experienced physical dispossession of their land or coercion to cooperate with enterprises (interview with palm oil smallholder in Partimbalan village, 25 October 2019). The conversion from subsistence crops to palm oil did not change the land ownership, and the smallholders still have the freedom to manage their land independently. However, the contract farming is a non-mandatory policy which the smallholders have the freedom to be involved or not. If the smallholders choose to be involved, they also have the freedom to choose the koperasi or enterprise to partner with. This indicates that accumulation is not realized under a regime of violent and physical appropriation, but with a tendency towards integration. Hence, land grabbing by dispossession does not occur.

Under the legal 'partnership' of contract farming, peasants experience a shifting labor relation in a new landscape of commodity. As dependent wage 'labor', they become subservient to the palm oil industry. The centralization of capital leads to smallholder land being operated under one single palm oil industrial enterprise. In other words, centralization through contract farming enables enterprises to employ labor (smallholders) and obtain means of production (palm oil fruit) based on legal agreements. Thus, accumulation without dispossession takes place since the enterprise increases its production but does not need to acquire land ownership.

Contract farming is a vehicle of agroindustrial capitalism for instilling capital logic into the social formation of subsistence farmers [29]. Contractually, the palm oil smallholder is allowed to sell and distribute their palm oil fruits to enterprises. The smallholder must comply with provisions in the contract, such as fruit quality, delivery time, and also sometimes planting management that must follow enterprise standards. The emergence of contract farming breaches the industrial logic of rural life by connecting smallholders to the palm oil industry. The radical transformation of industrial space logic is a signal of how the urban condition emerges in predominantly rural areas. However, the process of continuous accumulation is a strong explanation for how extended urbanization through industrial capitalism penetrates the countryside and alters the space by introducing a new urbanized socio-spatial organization [51].

Sei Mangkei Industrial District utilized contract farming to improve the scale of production because the raw materials on its land were insufficient to meet factory capacity (interview with production management of Sei Mangkei Industrial District, 24 October 2019). This occurred in 2011, when Sei Mangkei upgraded the mill production, followed by the designation as a Special Economic Zone. In 2013, there were eight koperasi that 
acted as a middleman for hundreds of palm oil smallholders around Simalungun Regency, who supplied their palm oil fruit to Sei Mangkei. This number increased to 10 koperasi in 2014 [52].

It should be noted that the palm oil smallholders such in Partimbalan or Pasar Baru village actually did not change the commodity production of their land because of the contract farming with Sei Mangkei, since this transformation had already been carried out two decades before because of the involvement of the NES program and voluntary abandonment of subsistence farming. Since then, the smallholders have also had a partnership with various palm oil enterprises through contract farming. However, we intend to show that Sei Mangkei reflects the palm oil enterprises' behavior to take advantage of contract-farming schemes in terms of increasing profit and scale of production and by carrying out the process of accumulation without dispossession. Accumulation without dispossession through contract farming is an effective tool for increasing palm oil productivity in congruence with the endeavor to maintain and expand the capital logic of extended urbanization in various regions. Extended urbanization is therefore no longer limited to the main sites of industrial enterprises, such as Sei Mangkei; rather, it is expanded or intensified to include smallholder land along with an increasing scale of accumulation.

\section{Smallholder's Everyday Life Practices and Struggles}

The success of the participants in the NES contract farming program has encouraged the expansion of independent smallholders who have voluntarily replaced their food crops with palm oil plantations. This is driven by the desire to improve the quality of life by utilizing the land they have to be more productive and economically efficient. At this time, the alternatives to obtaining a better job are few. Thus, the presence of opportunities to improve economic welfare is welcomed by the wider community. Unfortunately, the transformation of this commodity crop also encourages the transformation of culture and social relations of society that are inherent to the industrialization process. This is a process that might not always be profitable in the future, and the options are increasingly limited to remove oneself from dependence on capitalist social relations when commodity prices are falling.

The social configuration of the 'palm oil community' in the smallholders' life has given rise to a new landscape of lived space, such as economic rationalization, daily activities related to modern farming management, social interaction, and communication. As a cash crop and capitalist commodity, palm oil distribution must proceed through exchange activities with industry. Hence, the smallholder's life depends on how this industrial chain works, including the price of palm oil in the global market. Palm oil smallholders in Pasar Baru village expressed:

"If the price [of palm oil] collapses to the lowest level, the smallholders have to sell their land, which is their only asset, because they don't own anything else".

(Interview, 15 December 2019)

One could argue that although the extended urbanization of the palm oil smallholder landscape does not entail the physical dispossession of land during the industrialization process, we still find that feelings of anxiety remain in the smallholders' daily lives. This anxiety arises because of the ever-present threat of palm oil prices plummeting in the future (Field notes, 15 December 2019). This feeling is growing since palm oil smallholders have experienced such a crisis in 2008 (interview with palm oil smallholder in Pasar Baru village, 15 December 2019).

In this context, we also view that the smallholder who converts all the land they own into palm oil plantations does not have the option to access other economic activities when the price crisis occurs. This situation is a consequence that smallholders were not aware of in the past. This situation is similar to the capitalist relations of cocoa farmers in Sulawesi, as Tania Li [53] mentioned that there is 'erosion' in people's lives, "not dramatically, but piecemeal and by stealth, rather like the action of water on a stream bed that creates new pathways and makes old ones unusable or irrelevant, without anyone willing it to be so" 
(P. 116). In the contexts of palm oil smallholders' lives, extended urbanization has created a space for total dependence on industry and the global market because their economic activities must be realized in the exchange value of palm oil commodities. People may not realize a socio-economic transformation when they first change food crops to palm oil plantations.

The inability of palm oil smallholders to ensure their future lives due to their connectedness to and the uncertainty of global markets is a major factor for anxiety affecting their everyday lives. In the smallholder community, we identified two groups according to their responses regarding uncertainty about the future price of palm oil (Field notes, 15 December 2019). The first group included those who give up their life to future conditions because their ability to access other economic spaces is limited. Meanwhile, the second group included smallholders who still have small vacant land reserves and capital to carry out other economic activities. These smallholders choose to practice small-scale subsistence farming of crops (such as cassava or tropical fruits), which can be an alternative to meet their daily needs when a crisis of palm oil prices occurs.

In this sense, the farming of subsistence crops is a form of socio-economic resistance to deal with global market uncertainty. Although this practice does not threaten the logic (structure) of capital-based urbanization, it is an attempt to open an alternative space that values use values than total dependence on exchange values of the global market. In this extended urbanization process, resistance or struggle do not appear in the form of class conflicts. However, this practice is realized by imagining the other activities outside the logic of palm oil capital relations and is practiced on a smaller scale.

\section{Conclusions}

Under the regime of economic growth by palm oil industrialization, Indonesia has experienced a massive transformation of its rural industrial landscape. This industrialization occurred with a reconfiguration of the socio-spatial logic of space, from rural subsistence to an urban-industrial fabric/praxis depending on global capitalism. Referring to Lefebvre's notion of urbanization beyond urban-rural dualism, the rural landscape of Sei Mangkei in North Sumatra has become an integral part of industrial production. This paper examined how it encountered an extended urbanization process through agroindustrial extraction of palm oil. Crucially, the theoretical lens of extended urbanization helps us to see how the dynamic capitalist urbanization process expands beyond the metropolitan to territories that are conventionally classified as rural or hinterland. Thus space must be seen as historically continuous enforcement forged by a multiscalar and dialectical force between global structures of capital and local everyday practices.

Previous case studies on the mining (oil, metal, mineral), manufacturing, or timber industrial sectors tended to show that the urbanization of capital in extended urbanization space entails the mechanism of community land dispossession to instill an urban-industrial logic $[10,13,24,54]$. However, Sei Mangkei experienced a different process. The palm oil-based agroindustrial process in Sei Mangkei did not need to dispossess community land physically to accumulate capital. Rather, this occurred through the integration and centralization of smallholder land into a large industrial enterprise production chain, where the land owners, without coercion, transformed their lands into commodity crop land of their own accord. As such, industrial capitalism can promote extended urbanization without privatizing land.

As a consequence of the transformation of subsistence land into commodity crop land, smallholders' daily lives became more dependent on the global market. However, this situation brought limited options to access other economic activities when global prices were failing. Thus, the uncertainties surrounding the palm oil global market and palm oil prices cause anxiety and threaten smallholders' futures. As a result, instead of resistance against industrial and state institutions, the smallholder chooses to practice small-scale subsistence farming as a form of resistance and 'line of defense' [55] against the uncertainties of the global market. This process is a result of translating the thoughts and 
practices of palm oil smallholders as local-scale subjects to various global-scale structural forces, which, at a certain point (crisis), make them aware of the importance of other alternative forms without completely replacing the oil palm plantations they currently have. Instead of labelling oil palm smallholders as subjects who experience 'false consciousness' of the overall manipulation of the industrial class, we believe that this struggle practice is a form of negotiation and articulation carried out by palm oil smallholders. Thus, we highlight that the extended urbanization process was also co-produced by smallholder practices rather than solely dominated by the palm oil capitalist industry.

Finally, we state that extended urbanization is a part of a fruitful framework, not only in deciphering capitalist industrialization as a dominant force of large-scale abstraction, but also in everyday practice and the struggle of palm oil smallholders on a small scale. It shows that extended or planetary urbanization does not stand to generalize the urbanization process (urbanization is the same everywhere). On the contrary, there are differences in the socio-spatial formation under similar forces/tensions of the global phenomenon of capitalist industrialization. Thus, we assert that extended urbanization was (re)produced through the articulation of socio-economic and cultural practices of agency (smallholders) on a local scale towards the dynamic of broader process of global industrialization. This result complies with the current agenda of urban research in looking at the broader politicaleconomic forces of urbanization with regards to non-city space and exposing everyday struggles as an inevitable part of the multiscalar processes [54]. This analysis can be a starting point to open up the emancipatory possibility of the production of 'just space' and 'differential space', in which use value is more significant than exchange value [56].

Author Contributions: Conceptualization, I.P.P.; Investigation, I.P.P.; Methodology, H.W., D.H. and I.S.; Supervision, H.W., D.H. and I.S.; Writing—original draft, I.P.P.; Writing—review \& editing, H.W., D.H. and I.S. All authors have read and agreed to the published version of the manuscript.

Funding: This research was partially funded by the World Class Research (WCR) Program and Master Degree to Doctoral Scholarship Program for Excellence Undergraduate (PMDSU) under Indonesian Ministry of Education, Culture, and Higher Education.

Institutional Review Board Statement: Not applicable.

Informed Consent Statement: Not applicable.

Data Availability Statement: Not applicable.

Conflicts of Interest: The authors declare no conflict of interest.

\section{References}

1. Brenner, N. Globalisation as Reterritorialisation: The Re-scaling of Urban Governance in the European Union. Urban Stud. 1999, 36, 431-451. [CrossRef]

2. Vos, R. De Counter-Mapping against oil palm plantations: Reclaiming village territory in Indonesia with the 2014 Village Law. Crit. Asian Stud. 2018, 50, 615-633. [CrossRef]

3. Lefebvre, H. The Urban Revolution; Original Work Published 1970; University of Minnesota Press: Minneapolis, MN, USA, 2003; ISBN 0816641595.

4. Monte-Mór, R.L. What is the urban in the contemporary world? Cad. Saude Publica 2006, 21, 942-948. [CrossRef]

5. Brenner, N.; Katsikis, N. Operational Landscapes: Hinterlands of the Capitalocene. Archit. Des. 2020, 90, 22-31. [CrossRef]

6. Harvey, D. The urban process under capitalism: A framework for analysis. Int. J. Urban Reg. Res. 1978, 2, 101-131. [CrossRef]

7. Limonad, E.; Monte-Mor, R.L. Beyond the right to the city: Between the rural and the urban. Urbia 2015, 13, $103-115$.

8. Brenner, N.; Schmid, C. Towards a new epistemology of the urban? City 2015, 19, 151-182. [CrossRef]

9. Levien, M. Special economic zones and accumulation by dispossession in India. J. Agrar. Chang. 2011, 11, 454-483. [CrossRef]

10. Arboleda, M. Spaces of Extraction, Metropolitan Explosions: Planetary Urbanization and the Commodity Boom in Latin America. Int. J. Urban Reg. Res. 2016, 40, 96-112. [CrossRef]

11. Rincon, V.R.; Martinez-ALier, J.; Mingorria, S. Environmental Conflicts Related to Urban Expansion Involving Agrarian Communities in Central Mexico. Sustainability 2019, 11, 6545. [CrossRef]

12. Kanai, J.M. On the peripheries of planetary urbanization: Globalizing manaus and its expanding impact. Environ. Plan. D Soc. Space 2014, 32, 1071-1087. [CrossRef] 
13. Wilson, J.; Bayón, M. Concrete Jungle: The Planetary urbanization of the Ecuadorian amazon. Hum. Geogr. 2015, 8, 1-23. [CrossRef]

14. Ghosh, S.; Meer, A. Extended urbanisation and the agrarian question: Convergences, divergences and openings. Urban Stud. 2020, 58, 1097-1119. [CrossRef]

15. Sevilla-Buitrago, Á. Urbs in rure: Historical enclosure and the extended urbanization of the countryside. In Implosions/Explosions; Brenner, N., Ed.; Jovis: Berlin, Germany, 2014; pp. 237-259.

16. Marx, K. Capital; Penguin: New York, NY, USA, 1976; Volume I.

17. Leitner, H.; Sheppard, E. Provincializing Critical Urban Theory: Extending the Ecosystem of Possibilities. Int. J. Urban Reg. Res. 2016, 40, 228-235. [CrossRef]

18. Robinson, J.; Roy, A. Debate on Global Urbanisms and the Nature of Urban Theory. Int. J. Urban Reg. Res. 2016, 40, 181-186. [CrossRef]

19. North Sumatra Plantation Agency Statistik Perkebunan. Available online: http://disbun.sumutprov.go.id/statistik_2019/web/ index.php? $\mathrm{r}=$ site $\% 2$ Flaporan-komoditi\&tahun=2017\&komoditas=2 (accessed on 10 February 2020).

20. The Ministry of Environment and Forestry Rekalkulasi Penutupan Lahan Indonesia 2018; The Ministry of Environment and Forestry: Jakarta, Indonesia, 2019.

21. National Council of SEZ Indonesia Kawasan Ekonomi Khusus Indonesia. Available online: http://kek.go.id/ (accessed on 2 August 2020).

22. Angelo, H.; Wachsmuth, D. Urbanizing urban political ecology: A critique of methodological cityism. Int. J. Urban Reg. Res. 2015, 39, 16-27. [CrossRef]

23. Brenner, N.; Madden, D.J.; Wachsmuth, D. Assemblage urbanism and the challenges of critical urban theory. City 2011, 15, 225-240. [CrossRef]

24. Harvey, D. The New Imperialism; Oxford University Press: Oxford, UK, 2003.

25. Storper, M.; Walker, R. The Capitalist Imperative: Territory, Technology, And Industrial Growth; Blackwell: New York, NY, USA, 1989.

26. Harvey, D. The Urbanization of Capital: Studies in the History and Theory of Capitalist Urbanization; Johns Hopkins University Press: Baltimore, MD, USA, 1985; ISBN 080183144X.

27. Ronneberger, K. Henri lefebvre and urbaneveryday life: In search of the possible. In Space, Difference, Everyday Life: Reading Henri Lefebvre; Goonewarden, K., Kipfer, S., Schmid, C., Milgrom, R., Eds.; Routledge: New York, NY, USA, 2008.

28. Castriota, R.; Tonucci, J. Extended urbanization in and from Brazil. Environ. Plan. D Soc. Space 2018, 36, 512-528. [CrossRef]

29. Dubb, A. The value components of contract farming in contemporary capitalism. J. Agrar. Chang. 2018, 18, 722-748. [CrossRef]

30. Shrimali, R. Accumulation by Dispossession or Accumulation without Dispossession: The Case of Contract Farming in India. Hum. Geogr. 2016, 9, 77-88. [CrossRef]

31. Fine, B.; Saad-Filho, A. Marx's Capital, 6th ed.; Pluto Press: London, UK, 2016.

32. Little, P.; Watts, M. Introduction. In Living under Contract: Contract Farming and Agrarian Transformation in Sub-Saharan Africa; Little, P., Watts, M., Eds.; University of Wisconsin Press: Madison, WI, USA, 1994; pp. 3-20.

33. Sawaya, R. Subordinated Development: Transnational Capital in the Process of Accumulation of Latin America and Brazil; Koninklijke Brill NV: Leiden, The Netherlands, 2018; ISBN 9789004366466.

34. Murdoch, G. Timeline: Slaves, Colonials, Weevils: Palm Oil's Historic Rise. Available online: https://www.reuters.com/article/ us-indonesia-forest-palm-timelinesb-idUSTRE58M01I20090923 (accessed on 7 March 2020).

35. Soetrisno, L.; Winahyu, R. Kelapa Sawit: Kajian Sosial_Ekonomi; Aditya Media: Yogyakarta, Indonesia, 1991.

36. Sanders, J. Palm Oil production on the Gold Coast in Aftermath of Slave Trade: Case Study of the Dante. Int. J. Afr. Hist. Stud. 1982, 15, 49-63. [CrossRef]

37. Stoler, A.L. Capitalism and Confrontation in Sumatra's Plantation Belt, 1870-1979, 2nd ed.; University of Michigan Press: Ann Arbor, MI, USA, 1995.

38. Budidarsono, S.; Susanti, A.; Zoomers, A. Oil Palm Plantations in Indonesia: The Implications for Migration, Settlement/Resettlement and Local Economic Development. In Biofuels: Economy, Environment and Sustainability; Fang, Z., Ed.; InTech: Rijeka, Croatia, 2013.

39. Zen, Z.; Barlow, C.; Gondowarsito, R. Oil Palm in Indonesian Socioeconomic Improvement: A Review of Options. Working Paper in Trade and Economics; The Australian National University: Canberra, Australia, 2005.

40. Baudoin, A.; Bosc, P.-M.; Bessou, C.; Levang, P. Review of the Diversity of Oil Palm System in Indonesia Case Study of Two Provinces: Riau and Jambi; Center for International Forestry Research (CIFOR): Bogor, Indonesia, 2017.

41. Grenville, S. The IMF and the Indonesian Crisis. Bull. Indones. Econ. Stud. 2004, 40, 77-94. [CrossRef]

42. Tarmizi Legal Implication of Plantation Concessions during the Dutch Colonialism on the Contemporary Land Governance and Civil Rights. J. Leg. Ethical Regul. Issues 2019, 22, 1-13.

43. Waal, R. Guidlines for a Development Plan for the East Coast of Sumatra; Wageningen Durkkerij: Wageningen, The Netherlands, 1950.

44. Wasino, W. From A Colonial to A National Company: The Nationalization of Western Private Plantation in Indonesia. Lembaran Sej. 2017, 13, 109-115. [CrossRef]

45. Li, T.M. Social Impacts of Oil Palm in Indonesia: A Gendered Perspective from West Kalimantan; Center for International Forestry Research (CIFOR): Bogor, Indonesia, 2015. 
46. Baswir, R.; Achmad, N.; Santosa, A.; Wibowo, I.A.; Winarni, R.R.; Susanti, E.; Hasibuan, F.; Hanu, M.A. Pekebun Mandiri Dalam Industri Perkebunan Sawit Di Indonesia; Pusat Studi Ekonomi Kerakyatan Universitas Gajah Mada, Sawit Watch dan Serikat Petani Kelapa Sawit: Yogyakarta, Indonesia, 2010.

47. GAPKI. Sumatera Utara Industri Minyak Sawit Sumatera Utara Berkelanjutan; GAPKI: Bogor, Indonesia, 2016.

48. Ministry of Economic Coordinator Indonesia Luas Lahan Sawit Perkebunan Rakyat di Kabupaten Simalungun, Sumatera Utara 1996-2010. Available online: https:/ / databoks.katadata.co.id/datapublish/2016/05/12/luas-lahan-sawit-perkebunan-rakyatdi-kabupaten-simalungun-sumatera-utara-1996-2010 (accessed on 18 August 2019).

49. Marti, S. Losing Ground: The Human Rights Impacts of Oil Palm Plantation Expansion in Indonesia. 2008. Available online: https:/ / www.foei.org/wp-content/uploads/2014/08/losingground.pdf (accessed on 15 February 2008).

50. Wood, E. The Origin of Capitalism: A Longer View; Verso: London, UK, 2002.

51. Monte-Mór, R.L. Urbanization, Colonization and the production of regional space in the Brazilian Amazon. In Proceedings of the 16th Inter-American Congress of Planning, San Juan, Puerto Rico, 22-26 August 1988.

52. TÜV Rheinland. Roundtable on Sustainable Palm Oil Annual Surveillance Audit Report; TÜV Rheinland: Jakarta, Indonesia, 2014.

53. Li, T.M. Land's End Capitalist Relations on an Indigenous Frontier; Duke University Press: Durham, UK, 2014; ISBN 978-0-8223-5705-6.

54. Angelo, H.; Goh, K. Out in Space: Difference and Abstraction in Planetary Urbanization. Int. J. Urban Reg. Res. 2021, 45, 732-744. [CrossRef]

55. Hebinck, P.G.; Ploeg, J.D. Dynamics of Agricultural Production. An Analysis of Micro-Macro Linkages. In Images and Realities of Rural Life. Wageningen Perspectives on Rural Transformations; de Haan, H., Long, N., Eds.; Royal van Gorcum: Assen, The Netherlands, 1997; pp. 202-226.

56. Lefebvre, H. The Production of Space; Blackwell: Oxford, UK, 1991. 